\title{
Editors' Epilogue
}

\section{The animal turn: Into the sea with the fish-knights of Perceforest}

\author{
Karl Steel ${ }^{a}$ and Peggy McCracken ${ }^{b}$ \\ a Brooklyn College, City University of New York, New York. \\ bUniversity of Michigan, Michigan.
}

This volume and its collaborative character owe a great deal to Sarah Stanbury and the College of the Holy Cross, whose generosity made possible a meeting of the authors and editors at an early stage of composition.

postmedieval: a journal of medieval cultural studies (2011) 2, 88-100.

doi:10.1057/pmed.2010.50

1 For this locution, see Haraway (2008, 330 n33) who includes in this term 'microbes, fungi, human, plants, animals, cyborgs, and aliens.' She adds, 'I pray that all residual tones of creation have been silenced in the demotic critter.'
In his contribution to this volume, Cary Wolfe points out the 'terrestrialist bias that still obtains in [an] animal studies' that concentrates on 'dogs, cats, horses, and farm animals,' and perhaps less frequently, on birds and hideous fabulists. The world, on land and on sea, comprises many far less familiar 'critters' ${ }^{1}$ than these: anemones symbiotically reliant on 'little marshes of algae, ocean plantlets of a species that has come to live only in them' (Lingis, 2003, 165), deep-sea tube worms, cetaceans, or, legendarily, the whale-like aspidochelone, whose rocky and verdant back, resembling an island, lured unwary sailors to their deaths (Guillaume le Clerc, 1852, 1l. 2095-2120; Coulter, 1926; Szabo, 2008, 47-50). Few medieval critters so confused distinctions between land and sea, animal and land, and life and nonlife, but we do find other examples of beings that inhabit both land and sea in medieval texts. We turn, then, to the curious figure of the fish-knight in an epilogue that aims to extend the inquiries and conclusions of the preceding essays and to further unsettle the terrestrial and vitalist biases underlying many critical perspectives on nonhumans.

In what is surely one of the stranger episodes in medieval literature, found in the fourteenth-century Roman de Perceforest, the knight Bethidés has been 
taken by a spirit to an island where he can find no signs of habitation. As he wanders by the sea, the knight encounters a group of four-legged fish who come out of the sea to graze. These marvelous fish ('poissons tresmerveilleux'; Roussineau, 1991, 273) $)^{2}$ have short legs and fish tails, but otherwise they resemble familiar grazing animals. One has the head, fur and horns like a bull ('comme ung boef,' 273), others are like sheep or stags or bears. After these fish have eaten, they plunge back into the sea. The knight's view of the grazing fish is part of a narrative about hunger, chivalry and eating fish, and also, most obviously, about being taken out of one's element. It is winter on this island, and no fruits are in season. The only plants on the island are roots, herbs and leaves, and Bethidés is hungry. He is so hungry, he thinks, that he could eat an entire deer's leg completely raw. This is the moment at which, as if on cue, more marvelous fish, some in the form of deer, come out of the sea to graze, forming a scene at once littoral and sylvan. Famished, Bethidés draws his sword and kills several of the animals, but as he cuts them up, he sees four more fish approaching on two feet. These are fish knights, and although they are only the size of hunting dogs, their chests are wide and strong. Their heads have the shape of a helmet topped with a long point, like a sword, and a shield covers their backs from head to tail. As in Peter Travis's characterization of Aesop, these fish are 'situated at the folded frontier between the socalled animal and the so-called human ... disequilibrat[ing] those categorical boundaries within which we traditionally have prised apart the human subject and the animal object.'

As disequilibrating as they are, the 'poissons chevaliers' may not have been entirely unfamiliar to Perceforest's medieval readers, and an inventory of some similar beings in other antique and medieval sources may suggest the ways in which the romance develops the figure of the fish knight to question ethical as well as bodily distinctions. The opening to the ninth book of Pliny's Natural History attests to the extraordinary fertility of the sea, to how all things there so intertwine and interfold 'with each other now in one way and now in another, now by the action of the wind and now by that of the waves,' that the sea produces, as he says, 'a great many actual monstrosities' (Pliny, 1940, 165). Pliny's sea monsters are not, however, simply boundless and inchoate, an early witness to the 'postrepresentational' understanding of the 'seemingly anonymous materiality' of the sea promoted or critiqued by several of the essays in a recent PMLA cluster on oceans (for example, Chambers, 2010, 679). For within the same sentence Pliny describes these marine creatures not as monsters but rather as a nearly exact, familiar parallel to the terrestrial world (Kappler, 1999, 229-232; Leclercq-Marx, 2006): within the sea Pliny finds creatures 'resembling sheep,' and others 'with the heads of horses, asses, and bulls,' which emerge onto the shore to graze; these are likely the ultimate source for the livestock-like fish of Perceforest. More close at hand for Perceforest, Thomas of Cantimprés chapter on sea monsters in his thirteenth-century
2 Unless otherwise indicated, all translations of Perceforest are by the authors, and citations of the original text, by page number, refer to the Roussineau (1991) edition. An English translation of the Perceforest is forthcoming (Bryant, 2011). 
3 For discussions of this episode, see Douchet (2005, 295-305) and Taylor (2005, 183-184).

4 For a study of the several medieval variants of this episode, see Ross (1967).
Liber de natura rerum observes that 'the earth scarcely has any four-footed animal which is not found in some likeness in the sea' ('Vix enim terra animal quadrupes habet, quod non in parte simile mare habet,'232), and Gervase of Tilbery's Otia Imperialia, a frequently copied miscellany of anecdote and wonder, twice translated into French in the fourteenth century, asserts that 'there is no form of any creature found living among us [i.e., Britain] on dry land whose likeness, from the navel upwards, may not be observed among the fish of the ocean off Britain' (Gervase, 2003, 679; Pignatelli and Gerner, 2006, 274-275). Gervase then speaks of seapigs and dogs, not wholly alien creatures, and then produces creatures still more familiar: marine monks and, especially, 'the king-fish ... wearing its crown' ('rex piscis ... cornatus') and 'the knight-fish rid[ing] in armor' ('miles armatus equitat'), one of several representatives among what Christine Ferlampin-Acher has described as a heightened interest in fish knights towards the end of the Middle Ages (Ferlampin-Acher, 2002, 299).

It is possible that accounts of fish knights are inspired by medieval natural history - Marco Polo identifies the rhinoceros as a 'unicorn' (Ferlampin-Acher, 2002, 297), and the editor of Perceforest speculates that the author may have modeled his fish knights on the narwhal, also called a sea unicorn ('licorne de mer'; Roussineau, 1991, xxiv). But while the fish knights of Perceforest have certain features in common with the narwhal - the 'long point' on their heads 'like a sword' ('une longue pointe ... en maniere d'espee,' 274) and their ability to use their noses to blow water 'higher than the height of a man' ('faisoient saillir par leurs narines plus hault que la haulteur d'un homme,'278) - their closest analogs are other fish knights, like those in Gervase.

Other similar beings include the adversary of the young King Arthur in Le conte $d u$ Papagau, a warrior whose skin encloses mount, rider and armaments all together (Charpentier and Victorin, 2004, 188), ${ }^{3}$ and those fish observed by the legendary Alexander 'that had the form of terrestrial beasts that walk on their feet at the bottom of the sea, gathering the fruits of trees that grow there' ('qui avoient forme de bestes qui sont sor terre et vont sor lour piés ou fons de la mer, coeillant les fruis des arbres qui i croissent'), including those 'that looked like men and women and walked on their feet at the bottom of the sea and ate other fish just as in this world men eat other animals' ('qui avoient samblance d'oume et de feme et aloient sor lor piés au fons de la mer et se norissoient aussi des autres poissons comme li houme font en cestui monde des autres bestes'; Hikla, 1920, 232). ${ }^{4}$ Indeed, Perceforest draws on this very scene, when in the earliest part of the story, Alexander himself appears and recalls his discovery of 'fish called sea knights who had heads shaped like helmets with swords on top held by the hilt and with shields on their backs' ('une maniere de poissons que on appelloit chevaliers de mer, qui ont les testes façonnees a maniere de heaulme et au dessus tenant une espee par le pumel et par dessus le dos ung escu'; Taylor, 1979, 167). But the being most like 
Perceforest's fish knights is the legendary zytyron (Taylor, 2005, $184 \mathrm{n} 10$ ), a fish described by Albert the Great's natural history and, in virtually identical terms, by Thomas of Cantimpré and Vincent of Beauvais:

Zytyron, they say, is a sea animal which the ancients called 'soldier' [militem] and is large and very strong. The foreportion of this animal resembles an armed soldier, for its head is crested with a hard corrugated skin that looks like a metal war helmet; as if hanging from its neck is a long broad sturdy shield, unyielding in strength, hollow on the inside. Veins and nerves by which this shield is attached proceed as if from its neck and vertebrae; the shield itself, or carapace, has the shape of a triangle. Its forelegs, which are like arms, are long, very powerful and bifurcated; and the animal uses them to fight with extraordinary vehemence. (Albert the Great, 1987, 379; see also Thomas of Cantimpré, 1973, 249 and Vincent of Beauvais, 1964-1965 1624, 1318)

Descriptions of the zytyron make sense of its appearance in terms of a soldier's armor: it resembles an armed soldier, its hard skin is like a metal war helmet, and the animal uses these armor-like features to fight. He looks like a soldier and he fights like a soldier.

The fish knights are likewise armed, even made of arms, and as Bethidés discovers, they also embody chivalric social hierarchies and act according to elite conceptions of property, honor and entertainments. When Bethidés kills the fish deer, fish knights emerge to punish him, in essence, for poaching, since these fish knights first appear as keepers of animals. The metaphor describing the size of this first set of fish knights, 'as large as hunting dogs' ('de la grandeur d'un chien de chasse,' 274), suggests that they are simultaneously hunting animals and hunters, as if they were a concretized image of the intimate cooperation between chivalric hunter and canine servant so necessary for performing aristocratic domination (Crane, 2008). Bethidés successfully defends himself from the attack, but the next day an army of fish knights comes out of the sea to dislodge this invader. Arranged in ranks, they attack Bethidés in waves, and he kills so many of them that he is surrounded by their bodies and his assailants cannot reach him. The stand-off lasts 3 days, and Bethidés thinks he will die of thirst. He races for a fountain and begins to drink. On their short legs, the fish pursue Bethidés, renewing the combat when they catch up to him; Bethidés kills so many that he again immures himself safely amid their corpses. Another day passes, and he sees even bigger fish knights exit the sea, likewise arrayed in orderly ranks, but now accompanied by their king, whose helmet bears a crown ('sy avoit sus son heaume une couronne moult bien faitte,' 279), and who demands single combat with Bethidés.

Another arduous battle ensues between 'the two champions' ('les deux champions,' 281), the fish king is wounded, the exhausted combatants fall 
to the ground, and the fish king makes signs of peace, 'speaking' through gesture. This is a language common to the supposedly irrational 'mute beasts' of medieval romance, one of a host of examples asking that limitrophic (Derrida, 2008, 29-30) appraisals of barriers between the linguistic and nonlinguistic might attend to organs other than the tongue. And indeed, although the text gives few details, the peace-making between the two knights develops along with their ability to communicate. The fish king makes signs of humility and peace, and Bethidés understands his meaning ('le roy des poissons lui commença a faire moult de admiracions en signe de humilité et de paix, et tant que le chavalier cognut tresbien son intencion'; 282). Bethidés accepts the king's offer, and the two share a drink and a meal of a red fish with marvelous healing properties. Bethidés then accompanies the fish king to the shore, and the king behaves 'as though he had the reason and conduct of a human man' ('comme s'il eust eu sens et conduite d'homme humain,' 282). At the shore, the fish king signals to the knight that he should witness a demonstration of his power. Bethidés understands the gestures and looks towards the sea ('Quant le gentil chevalier eut cogneu les signes de ce roy, il commença a regarder en la mer,' 283); there he sees the multitudes of fish knights who serve the king, aligned in ranks, the points on their helmets resembling a vast forest. Communication makes the fish king more like a human man ('homme humain'), and the spectacle of his great army makes him more like a human king.

The next day, the fish king returns, offers food to Bethidés, and then pulls him with his teeth in a sign that he wishes for him to participate in tourneying with the fish knights, none of whom considers himself worthy unless he does battle with Bethidés ('et leur sambloit bien que nul de eulx ne devoit estre tenu pour preu s'il n'avoit tournoyet a lui,' 284). During the ensuing 6 months, Bethidés fights the fish knights for an hour every day - since the fish cannot stay out of the water for any longer - and then he is finally rescued by a passing ship and takes to the sea himself.

Like the knight who comes from the sea to attack a lady's knights and claim her lands in Le conte $d u$ Papagau, the fish knights of Perceforest do not stay where they should. They confound the distinction between land and sea, and between land life and sea life. The aquatic piscine worlds Pliny speaks of and that Alexander witnesses parallel the terrestrial world conceptually without ever crossing into it. Each world stays in its place, echoing the other. Yet when the fish knights come ashore, the distinction between land creatures and sea creatures blurs, as do a host of other apparently fundamental distinctions: between human and animal, culture and nature, licit and illicit edibility, and even that between life and nonlife. The fish knights appear as an assemblage of living being and prosthetic technology, showing how knighthood can, in Susan Crane's words, 'encompass embodiment and materiality in constituting the chivalric self,' and raise questions about the 'mechanical aspect' of parts of the body to such a degree as to render radically indistinct the difference 
between limb and prosthesis, embodiment and materiality, and the organic and the inorganic. Per Albert the Great, the fish knight's shield is part of its body, attached by veins and nerves; it is not a technology added to the fish knight but simply another, albeit uncannily familiar appendage. Not being a scientific compendium, Perceforest is more willing than Albert to raise rather than to resolve questions, and indeed, the text seems sometimes to suggest that the armor is part of the fish knights' bodies, and sometimes to suggest that it is noncorporeal technology carried or worn by the fish knights. They have heads like helmets ('en guise de heaumes,' 274) and they have long points, like swords, on the top of their heads ('au dessus du comble de leurs testes, ilz avoient chascun une longue pointe ... en maniere d'espee,' 274). But in addition to the sword on his head-helmet, the fish king carries a different kind of point on his back, one that he can manipulate (with his hands?): 'The king rose to his feet and placed before him a long point made of bone whiter than ivory, and that hung behind him on his back, and he held it like a unicorn holds its horn' ('le roy se leva sus ses piez et puis dressa pardevant lui une longue pointe d'oz, plus blanche que yvoire, qui lui gisoit sus le dos par derriere, et la tenoit comme une licorne fait la sienne'; 280). The fish king is larger than his knights, he wears a 'well made' crown ('moult bien faitte,' 279), and he has a second weapon, but his chivalric accoutrements are no less ambiguously related to his body than those of his knights. This is particularly apparent in the descriptions of shields. When the fish knights first appear, the text explains, 'each one [of the fish knights] had something like a shield on its back that covered its spine from the head to the tail' ('sus le dos ilz avoient comme ung escu que toute l'eschine leur couvroit depuis la teste jusques a la queue,' 274); yet Perceforest never explains what the fish knights have that is 'like a shield,' whether this is a bone, a leathery flap of skin, or a tool, organic perhaps but not quite corporeal. Nor does it ever explain the difference between these shieldlike objects or appendages and shields themselves. For in combat, the shields of the fish operate precisely as a shield should. During his fight with the fish king, Bethidés, sorely pressed, tries to land a blow, but the king ducks forward and the sword falls on the shield that covers his back ('Mais le roy clina la teste par derriere et l'espee chey sus le dur de son escu, dont il avoit le dos couvert'; 280). Perceforest remarks on the peculiar sound this blow makes: 'the blow sounded as though it fell on a table and didn't damage the shield at all' ('le coup mena tel son que s'il fust chut sus une table et ne empira en riens l'escu,' 280); yet this sound - a metal sword striking a wooden barrier - is the very sound such a blow should make, given that shields were in fact made primarily of wood. All that makes this shield strange is that it is - apparently - a limb. Yet when Bethidés finally draws blood, he wounds the fish king by striking it 'near the shield' ('au prez de l'escu,' 280), as if it were impossible to draw blood from the shield itself, as if, in other words, this shield were a technological object capable only of being damaged rather than wounded. The fish-knights' 
weapons are both familiar and strange, they are both of the body and on the body, and the distinction seems essential to understanding these beings: do they act from the body, either as animals or as quasi-organic automata, or do they act as bearers of weapons, as adversaries who act from reason rather than instinct?

Come to punish Bethidés for poaching, the fish knights 'were so noble by nature that they did not try to attack [Bethidés ] all together' ('de leur nature estoient sy francs qu'ilz ne l'avoient daigné assaillir tous ensamble,' 276). Such scruples locate them in the world of noble battle rather than in either the wild of creature combat or the mechanical activity of automata. Perceforest's identification of their nobility as natural is unusually direct. In other instances, Perceforest describes resemblance or likeness: the horns on the fish knights' heads are 'like a sword' ('en maniere d'espee,' 274); the fish knights arrange themselves into groups that to Bethidés 'seem like a battalion of armed men' (sambloit une bataille de gens d'armes,' 276); and they have feet 'like a swan's' ('a la façon d'un cisne,' 278). But their nobility is theirs, directly, not a likeness or recollection of something evidenced more authentically elsewhere. Certainly this direct attribution of nobility might be read ambiguously: it might indicate an instinctual, automatic character in which these knights might be 'prisoners of their function' (Victorin, 2002, 415; see also Huot, 2007, 63), so wholly and authentically inhabiting or inhabited by their natural chivalric form that they cannot be anything but chivalric. But the noble knight Bethidés has hardly any more freedom, for a chivalric hero, so armored and trained and caught in a narrative like this, must act as he does. Like the fish knights, Bethidés is unable to abandon, or, it might be said, is unable not to choose chivalric behavior.

Nor is he able entirely to abandon appetite and instinct. Apart from fear and wonder, the sensation that Perceforest most frequently ascribes to Bethidés is hunger, an irresistible sensation that 'chases him' ('le chassoit,' 276), causing him to act almost instinctually. He escapes these unwilled choices only at the end of the episode, when he flees, rescued by a chance encounter with lost sailors. But for the space of this episode, Perceforest, like Jane Bennett, questions the 'onto-theological binaries of life/matter, human/animal, will/ determination, and organic/inorganic' (Bennett, 2009, x). Like the encounters Bennett describes, the encounter between Bethidés and his fellow armored subjects cannot be adequately comprehended as one of active organic agents confronting and shaping 'passive objects and their law-governed,' merely deterministic 'mechanisms' (Bennett, 2009, xiv). The encounter compels a rethinking of the distinction between instinctual and free response (Derrida, 2008, 119-140), undermining, like the horse Arondel in Gary Lim's study, 'the assumption that instinct and rational choice are always incompatible.'

Perceforest confronts this assumption perhaps most forcefully not in the behavior of the fish knights, but in the comportment of the human. After defeating the first set of fish knights, Bethidés behaved monstrously towards his 
defeated opponents, treating them only like dead animals, whose bodies and lives merit only instrumental treatment:

... de son espee il lieve l'escu que le poisson avoit sus le dos, et se treuve que dessoubz il estoit plus blancq que nesge. Sy en coupa une piece au long de l'eschine, dont il menga, et le trouva sy doulx et sy appetissant que oncques il n'avoit mengié sy bonne viande, se lui sambla. Et quant le chevalier eut mengé de ce poisson a sa voulenté, il en print pour vivre trois jours et le mist sus l'escu du poisson, et puis sus une roche ou sourdoit une clere fontaine. (276)

[Using his sword, he lifted the shield on the fish's back and found that underneath he was whiter than snow. Then he cut a piece from along the spine and ate it, and he found it sweet and delicious, and thought that he had never eaten such good food. And when the knight had eaten as much of this fish as he wanted, he took enough for three days and put it on the fish's shield, and then put it on a rock cooled by a clear fountain.]

Whatever the similarities between Bethidés and his opponents, once they become mere prey, they have ceased to be treated as human. But Bethidés's enjoyment of the fish shifts the scene of eating from being a straightforward act of human domination and humanizing self-distinction into a more ambiguous realm of pleasure. By describing the fish knight's flesh as 'whiter than snow,' Perceforest uses a trope more suitable for the aristocratic skin tone of a romance heroine than for the flesh belonging to a creature suitable for eating. In this case, the dead fish knights are the true knights, and Bethidés the ravenous wolf in their pasturage, the 'monstrous creature' (Huot, 2007, 60) bestially devouring their noble bodies. Furthermore, the characterization of the flesh as 'sweet,' and better than any other food, also echoes a cliché of chivalric narrative on the taste of human flesh, often purported to be the most restorative and most delicious of meats. A famous instance occurs in Geoffrey of Monmouth's History of the Kings of Britain, when King Cadwallo, driven into exile by his brother Edwin, lands on the Isle of Guernsey and, in his grief, refuses to eat until someone can provide him with venison. Cadwallo's beloved nephew, Brian, fails in his hunt, but rather than return with nothing, he slices off and roasts a piece of his own thigh and serves it to his uncle, who finds the flesh sweeter than any he had ever tasted before ('tantum dulcedinem in aliis carnibus non reperisset'; Geoffrey of Monmouth, 2007, 267). The singular deliciousness of the flesh attests to the special relationship between Brian and Cadwallo, to the nobility of Brian's corporeal sacrifice, but also to the inferiority of animal to human flesh and, as in Perceforest, to the superiority of aristocratic flesh to any other. ${ }^{5}$ In short, this fish flesh is strange, but it is strange in the way that human flesh, and especially elite flesh, is strange.

5 This paragraph includes material from Steel's 
forthcoming book How to Make a Human (2011).
Bethidés, freely feasting on the butchered fish-knights, displays no compunction about his diet until later in the narrative, when the defeated, 'human man'like fish king beheads one of his own knights for Bethidés and urges him to eat the flesh. Perceforest vehemently challenges the legitimacy of Bethidés's diet, for the king might have slaughtered and presented one of the deer-fish or cow-fish marvelous animals, to be sure, but also more clearly suitable for eating, at least from a 'human man' perspective. Bethidés and the king would then have occupied the stratum of rational nobility together, standing above the degraded, properly edible stratum containing irrational animals. Instead, the king, like the other fish, is a vegetarian, for once the king kills his knight, he and his remaining army turn immediately to their own meal, on grazing lands that they find so good 'that they will not permit that anyone live on the island' ('leur estoit sy bonne qu'ilz ne souffroient pour rien que personne en celle isle demourast,' 283). Vegetarian, wordless and therefore lacking any claim to a disembodied logos, belonging to a species without any apparent gender distinctions, the king does not join Bethidés in a regime of carnophallogocentrism (Derrida, 2008, 104). Instead, he chooses a fish nearly as noble as himself, killing it in a method that recalls not slaughter but execution, and offers it to Bethidés to eat. No wonder, then, that 'the noble knight did not wish to do so' ('le gentil chevalier n'en voult riens faire,' 283). Bethidés demonstrates his nobility in his reluctance to eat the slaughtered, or executed, or sacrificed fish knight, but what nobility could match the largesse of the king, who willingly gives up one of his own to the horror of anthropo-, or rather, ichthyophagy? And how can Bethidés maintain his nobility when he must eat? As Sylvia Huot notes, in the expanded version of the romance in Manuscript $\mathrm{C}$ we learn that the fish knights 'were so marvelously favorable to [Bethidés] that they did not allow him to go hungry' ('l'avoient tellement en grace que merveilles ne ilz ne souffroient point qu'il eust quelque disette de mengier'; 413), but this passage does not name what they gave the knight to eat. Huot concludes: 'If not their fellows, what then might they have been feeding him?' (Huot, 2007, 61). Is Bethidés chased by his hunger to commit acts that he now recognizes as ignoble? As if unwilling either to sully the reputation of its hero or to decide on the nobility of his acts, Perceforest remains silent about what Bethidés eats and where he finds nourishment. Rather than deciding what Bethidés does and what he should do, it holds the decision open, perhaps unable to escape the ethical conundrum created by the boundarycrossing beings that come from the sea to graze, to fight, and to offer noble companionship on land.

After first raising questions about the distinctions between tools and appendage and between choice and instinct, Perceforest finally turns its attention to questioning the foundational act by which humans distinguish themselves from other worldly life, namely, the act of domination through which humans convince themselves of their singular rationality and of the mere irrational instrumentality of everything else (Steel, 2008). Bethidés had 
started the episode unthinkingly confident in his being a human subject in a world of nonhuman, useable objects. Soon after arriving on the island, he longs to kill and eat an animal, and soon accomplishes his desire. His certainty in the legitimacy of killing for food continues even after Perceforest introduces a series of honorable, chivalric fish. Only when Bethidés receives an executed fish as a gift from the fish king does he appear to reconsider his diet and perhaps to recognize that his piscine opponents might not be objects, properly available for human use. He realizes perhaps that these beings have a face, that which calls out to a subject to recognize the infinity of another, what cannot be used up in any representation or categorization (Levinas, 1996, 9-10). The face says 'thou shalt not kill,' and, as Derrida observes, 'consequences follow [from this] upon one another, and must do so continuously: thou shalt not make him suffer, which is sometimes worse than death, thou shalt not do him harm, thou shalt not eat him, not even a little bit, and so forth.' The limitless consequences of this fundamental injunction have 'never been understood within the Judeo-Christian tradition, nor apparently by Levinas, as "Thou shalt not put to death the living in general", (Derrida, 1995, 279), since, for Levinas, generally, the face is human and therefore not wholly other (Derrida, 2008, 112). Levinas could permit his ethical attention to linger on the childlike cheerfulness of dogs, as he allowed that they might at least remind humans of their duties to (human) others. Levinas was more reluctant, however, to grant this attention to colder, less familiar animals - as he remarked, 'I don't know if a snake has a face' (Calarco and Atterton, 2004, 49) - or to allow that an animal's face might compel an ethical duty to animals themselves. How much more reluctant would he have been to grant the face to fish, so alien to humans, only infrequently granted recognition as having a life like that of other, more familiar animals?

The fish's strange difference from mammals, and perhaps even its perceived facelessness, gives it a particular kind of edibility for medieval thinkers. The penitentials, early medieval Christian handbooks detailing sin and punishments, tended to exempt fish from their injunctions against the human consumption of carrion; as one explained, 'fish are allowable [for eating, regardless of whether or not a human has killed them] because they are of another nature ('pisces licet comedere quia alterius natura sunt'; Bezler, 1998, 12). Centuries later, Aquinas likewise judges fish to be alive in a different sense than other animals. Scripture, he writes,

does not call fishes 'living creatures,' but 'creeping creatures having life'; whereas it does call land animals 'living creatures' on account of their more perfect life, and seems to imply that fishes are merely bodies having in them something of a soul, whilst land animals, from the higher perfection of their life, are, as it were, living souls with bodies subject to them. (Summa Theologica 1a, q. 72; Aquinas, 1947, 1:351) 
For Aquinas, because fish were less like humans in body than quadrupeds, they did not invigorate the body as much as other flesh; they were therefore suitable food for Lent, a time of penance and self-denial (Summa Theologica 2a2ae, q. 147, art. 8; Aquinas, 1947, 2:1792). Like the penitentials, like Aquinas, Perceforest treats fish as another kind of life, beyond or beneath that which Bethidés possesses. The fish knights exhibit characteristics of cyborgs; they arrive not as individuals but as a faceless swarm; they go to their deaths automatically; they die bloodlessly, wordlessly, without pleading, apparently without any emotion but implacability. Then the king arrives, and Bethidés must reevaluate his relation to these uncertainly alive figures. In his reluctance to eat, Bethidés might be recognizing that the fish knights are like him in being knights: rational, honorable, masters of elite technology, enthusiasts for an elite culture. This would be another humanism, only with a piscine face. Alternatively, the knight's understanding of the armored flesh of the fish knights may offer an example of visagéité (or, 'faciality') used by Deleuze and Guattari to describe the impetus to translate body into significance by envisaging it as an always already semiotic and subjectifying surface, and deployed by Sarah Kay so productively as a model of medieval reading. What Kay defines as 'the semiotic and subjectifying apparatus of "faciality" may here be located in the armor that is like that of a knight in that it signifies chivalric selfhood and desire, but unlike that of a human knight in that it is part of the animal body; or in the delectable white flesh of the fish knights, like that of a nobleman or woman, that confounds the distinction between eater and eaten.

Perceforest does not explain Bethidés's reluctance to eat what is offered him. In this hesitation, Perceforest holds out the possibility, as Levinas once did, that Bethidés is recognizing that a thing might have a face (Levinas, 1996, 10); or that in Bethidés's hesitation, perhaps like Perceval or Lancelot's catatonia (Deleuze and Guattari, 1987, 173-174), we are witnessing a deterritorialization of knights and fish and indeed of them together with this aquatic and littoral region, which, disoriented from becoming yet another recognizable face, are instead on the verge of conjoining into 'strange new becomings, new polyvocalities' (Deleuze and Guattari, 1987, 191); or that any number of supposedly foundational divisions, including those that distinguish critical animal studies from 'thing studies,' provide a foundation that lasts only so long as they remain unexamined. During his reluctance to eat, Bethidés has been thrown, so to speak, into the ocean, and with him a host of certainties, now floating or drowning in a space of no solidity but of immense and always shifting weight.

\section{About the Authors}

Karl Steel is Assistant Professor of English at Brooklyn College, City University of New York. He has published on critical animal studies and Shakespeare. 
His first book, How to Make a Human: Animals and Violence in the Middle Ages (Ohio State University Press), will be published in Fall of 2011 (E-mail: ksteel@brooklyn.cuny.edu).

Peggy McCracken is Professor of French and Women's Studies at the University of Michigan. Her latest books include The Curse of Eve, the Wound of the Hero: Blood, Gender, and Medieval Literature (Pennsylvania, 2003) and the co-edited volume, with Basil Dufallo, Dead Lovers: Erotic Bonds and the Study of Premodern Europe (Michigan, 2006) (E-mail: peggymcc@umich.edu).

\section{References}

Albert the Great. 1987. Man and the Beasts (De Animalibus, Books 22-26), trans. J. J. Scanlan. Binghamton, NY: Medieval \& Renaissance Texts \& Studies.

Aquinas, T. 1947. Summa Theologica, trans. Fathers of the English Dominican Province, 3 Vols. New York: Benzinger Bros.

Bennett, J. 2009. Vibrant Matter: A Political Ecology of Things. Durham, NC: Duke University Press.

Bezler, F., ed. 1998. Paenitentialia Hispaniae. Turnholt, Belgium: Brepols.

Bryant, N. forthcoming. Perceforest: The Prehistory of King Arthur's Britain. Cambridge, UK: D.S. Brewer in press.

Charpentier, H. and P. Victorin, eds. 2004. Le conte du Papegau. Paris: Champion.

Chambers, I. 2010. Maritime Criticism and Theoretical Shipwrecks. PMLA 125(3): 678-683.

Crane, S. 2008. Rituals Aspects of the Hunt à Force. In Engaging with Nature: Essays on the Natural World in Medieval and Early Modern Europe, eds. B.A. Hanawalt and L.J. Kiser, 63-84. Notre Dame, IN: University of Notre Dame Press.

Calarco, M. and P. Atterton, eds. 2004. Animal Philosophy: Essential Readings in Continental Thought. London: Continuum.

Coulter, C. 1926. The 'Great Fish' in Ancient and Medieval Story. Transactions and Proceedings of the American Philological Association 57: 32-50.

Deleuze, G. and F. Guattari. 1987. A Thousand Plateaus: Capitalism and Schizophrenia, trans. B. Massumi. Minneapolis, MN: University of Minnesota Press.

Derrida, J. 1995. 'Eating Well,' or the Calculation of the Subject. In Points: Interviews, 1974-1994, ed. E. Weber, trans. P. Connor and A. Ronnell, 255-287. Stanford, CA: Stanford University Press.

Derrida, J. 2008. The Animal that Therefore I Am, ed. M-L. Mallet, trans. D. Wills. New York: Fordham University Press.

Douchet, S. 2005. La peau du centaure à la frontière de l'humanité et de l'animalité. Micrologus 13: 285-312.

Ferlampin-Acher, C. 2002. Fées, bestes et luitons: Croyances et merveilles dans les romans français en prose (XIIIe-XIVe siècles). Paris: Presses de l'Université de Paris-Sorbonne.

Geoffrey of Monmouth. 2007. The History of the Kings of Britain, ed. M.D. Reeve, trans. N. Wright. Woodbridge, UK: Boydell and Brewer. 
Gervase of Tilbury. 2003. Otia Imperialia: Recreation for an Emperor, trans. and eds. S.E. Banks and J.W. Binns. Oxford, UK: Clarendon Press.

Guillaume le Clerc. 1852. Le Bestiaire Divin, ed. C. Hippeau. Caen: Imprimeur-Libraire. Haraway, D. 2008. When Species Meet. Minneapolis, MN: University of Minnesota Press.

Hikla, A, ed. 1920. Der altfranzösische Prosa-Alexanderroman: nach der Berliner Bilderhandschrift nebst dem lateinischen Original der Historia de preliis (Rezension J2). Halle: Niemeyer.

Huot, S. 2007. Postcolonial Fictions in the Roman de Perceforest: Cultural Identities and Hybridities. Cambridge, UK: D.S. Brewer.

Kappler, C. 1999. Monstres, démons et merveilles à la fin du Moyen Age, 2nd edn. Paris: Payot and Rivages.

Leclercq-Marx, J. 2006. L'idée d'un monde marin parallèle du monde terrestre: emergence et développements. In Mondes marins du moyen-âge: actes $d u$ 30e colloque du CUER MA, 3, 4, et 5 mars 2005, ed. C. Connochier-Bourgne, 259-271. Aix-en-Provence: Publications de Universitaire.

Levinas, E. 1996. Is Ontology Fundamental?. In Emmanuel Levinas: Basic Philosophical Writings, eds. A.T. Peperzak, S. Critchley and R. Bernasconi, trans. P. Atterton, rev. S. Critchly and A. Peperzak, 3-10. Bloomington, IN: Indiana University Press.

Lingis, A. 2003. Animal Body, Inhuman Face. In Zoontologies: The Question of the Animal, ed. C. Wolfe, 165-182. Minneapolis, MN: University of Minnesota Press.

Pignatelli, C. and D. Gerner, eds. 2006. Les Traductions des Otia Imperialia de Gervais de Tilbury par Jean d'Antioche et Jean de Vignay: Edition de la troisième partie. Geneva: Droz.

Pliny the Elder. 1940. Natural History: Books 8-11, trans. and ed. H. Rackham. Cambridge, MA: Harvard University Press.

Ross, D.J.A. 1967. Alexander and the Faithless Lady: A Submarine Adventure. London: J. W. Ruddock and Sons.

Roussineau, G., ed. 1991. Perceforest, Vol. 2. Geneva: Droz.

Steel, K. 2008. How To Make a Human. Exemplaria 20(1): 3-27.

Steel, K. forthcoming. How to Make a Human: Animals and Violence in the Middle Ages. Columbus, OH: Ohio State University Press, in press.

Szabo, V.E. 2008. Monstrous Fishes and the Mead-Dark Sea: Whaling in the Medieval North Atlantic. Leiden, The Netherlands: Brill.

Taylor, J.M.H., ed. 1979. Le roman de Perceforest, première partie. Geneva: Droz.

Taylor, J.M.H. 2005. Pursuing the Parrot: Writing the Quest in Late Arthurian Romance. In The Fortunes of King Arthur, ed. N.J. Lacy, 181-194. Cambridge, UK: D. S. Brewer.

Thomas of Cantimpré. 1973. De natura rerum, ed. H. Boese. New York: Walter de Gruyter.

Victorin, P. 2002. Le perroquet en cage et le chevalier Arthur dans le Chevalier du papegau: le monde l'autre monde et l'immonde. In Le monde et l'autre monde; Actes du colloque arthurien de Rennes (8-9 mars 2001), eds. D. Hüe and C. Ferlampin-Acher, 397-423. Orléans: Paradigme.

Vincent of Beauvais. (1964-1965, 1624). Speculum Quadruplex sive Speculum Maius. Douai. Reprint, Graz, Austria: Akademische Druck. 